\title{
Platelet functional responses and signalling: the molecular relationship. Part 1: responses.
}

\author{
by Anastasia N. Sveshnikova ${ }^{1,2,3}$, Maria G. Stepanyan ${ }^{1,2}$ and Mikhail A. Panteleev ${ }^{1,2,3 \#}$
}

1. Faculty of Physics, Lomonosov Moscow State University, 1/2 Leninskie gory, Moscow, Russia, 119991

2. Center for Theoretical Problems of Physicochemical Pharmacology, Russian Academy of Sciences, 30, Srednyaya Kalitnikovskaya str., Moscow, Russia, 109029

3. National Medical Research Centre of Pediatric Hematology, Oncology and Immunology named after Dmitry Rogachev, 1 Samory Mashela St, Moscow, Russia, 117198

\# Correspondence: editor@sbpreports.com

Received: 22.03.2021

Accepted: 29.03.2021

Published: 31.03.2021

DOI: 10.52455/sbpr.01.202101014

\section{Abstract}

Blood platelets are small anucleated cells whose main function is to form a plug upon vascular damage to stop bleeding. This role involves a number of functional responses induced by different agonists and coordinated by an intricate network of signal transduction pathways. Understanding this network is vital from both basic research point of view and for the purposes of drug target identification in thrombosis and hemostasis. This review series will focus on the regulation of platelet signalling, on tracking the molecular relationship between receptor activation and functional responses, and on the networking aspects of these pathways. The present paper, first one out of two, focuses on the description of platelet functional responses and of the conditions for their triggering.

Keywords: hemostasis, thrombosis thrombus formation, platelet activation, platelet intracellular signaling.

\section{Introduction}

The process of hemostasis is a spatiotemporally regulated physiological response [1] aiming to stop bleeding upon vascular injury. Blood platelets play a critical role in this response. They actually have a number of critical roles in human physiology, which include formation of the hemostatic plug upon injury [2], acceleration of the membrane-dependent reactions of blood coagulation [3,4], maintenance of vascular integrity [5-7], modulation of immune responses [8-10], tissue growth and regeneration $[11,12]$. In order to perform these urgent functions when and where it is needed, platelets rely on their huge network of receptors and signal transduction pathways.

The functional responses of platelets to stimulation are numerous [13] (Fig. 1), and the number of positive and negative stimuli to be processed by the

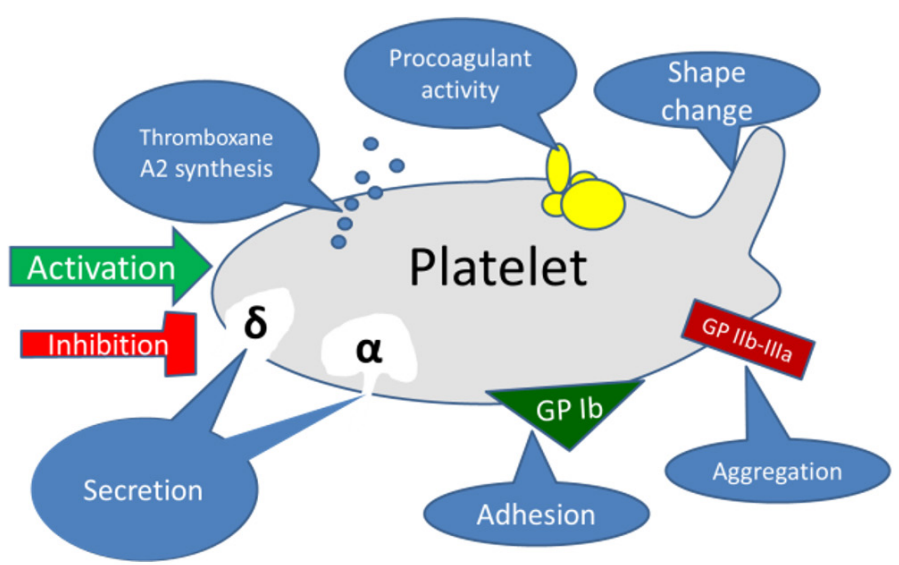

Figure 1. Scheme of the main platelet functional responses to activation (all of them could be blocked by inhibition). Blue ovals represent functions; yellow ovals represent blood coagulation factors, that can assemble on the surface of procoagulant platelets; GPIIb-IIla is the main (but not only) platelet integrin, which determines platelets aggregation; GPIb represents receptor complex for von Willebrand factor, which determines the initial adhesion of platelets to the site of injury.

cellular signalling networks in order to make correct decisions is likewise not small [14]. Additionally, a number of platelet inhibitory signals has been identified in recent years $[15,16]$. As a result, the network of platelet signal transduction that is initiated by at least ten major receptors, goes through multiple interconnected pathways and ends up with various responses of different degree might appear quite terrifying (Fig. 2).

When these pathways are reviewed and discussed, they are usually analyzed not as a network but rather as a simpler cause-and-effect chain. For example: activator $X$ stimulates receptor $Y$ leading to an increase of a secondary messenger $Z$ that mediates further downstream events, including responses "1", "2", and "3". The interplay of different receptors that could work cooperatively or downregulate each other is often overlooked. Interestingly, in other fields like immunology, terms like "co-activator" or "coreceptor" have already became accepted $[17,18]$. Likewise, transformation of the signal along the Cite as: Sveshnikova A.N., Stepanyan M.G. and Panteleev M.A.; t; SBPReports 2021 March 31; 1 (1) pp. 20-28 


\section{SBP I Reports}

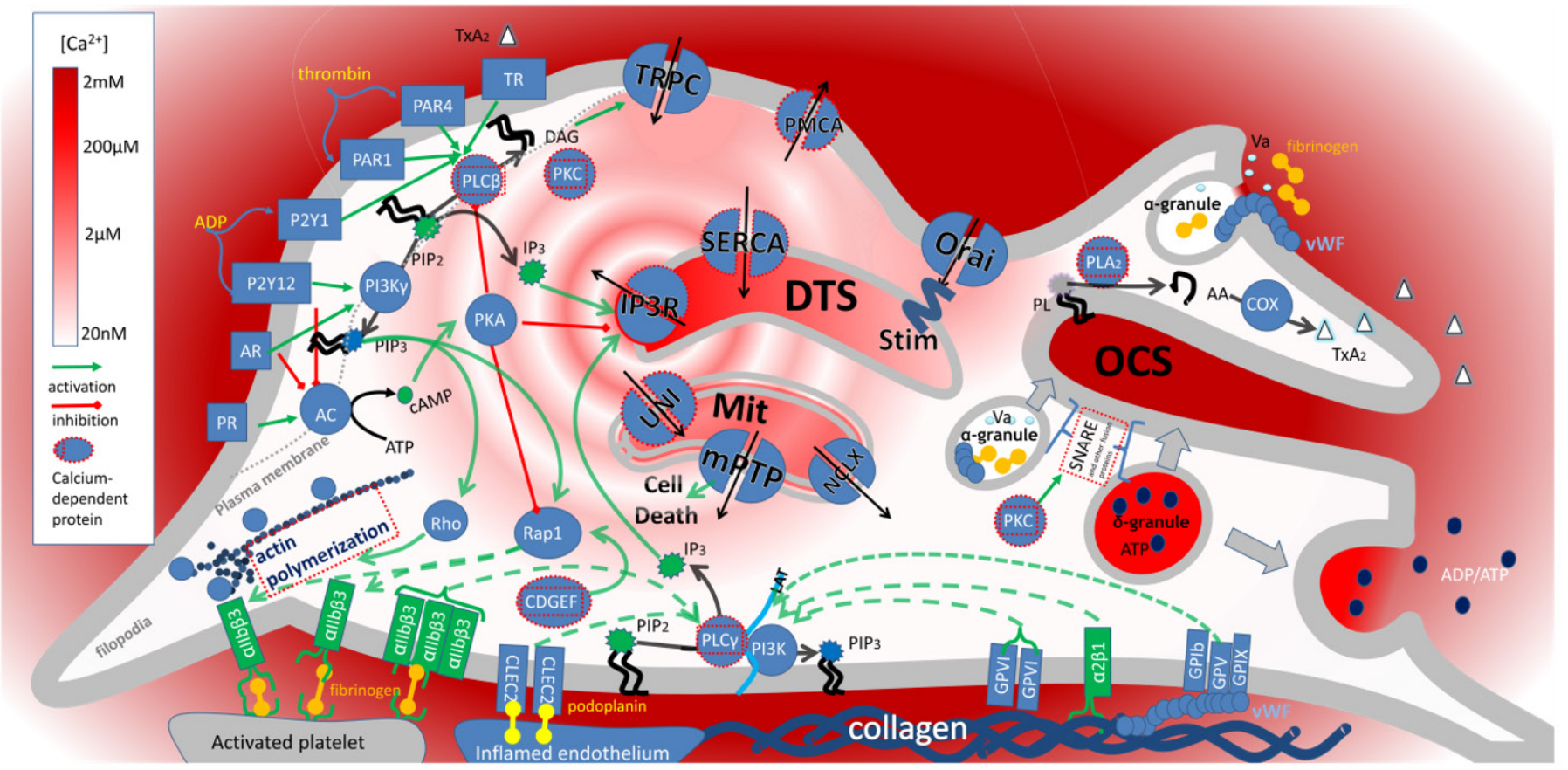

Figure 2. Scheme of the relationship between platelet-activating agents (thrombin, ADP, collagen, thromboxane A2, vWF, podoplanin and adrenalin) and platelet functional responses (shape change depicted by filopodia formation, adhesion and aggregation depicted by integrin activation, granule secretion and thromboxane A2 synthesis). All types of platelet activation lead to activation of phospholipase C (PLC) and, in most cases, phosphoinositide-3-kinase (PI3K). These enzymes lead to production of the two most important for platelets second messengers - calcium (shown in shades of red) and phosphoinositide-3,4,5-triphosphate (PIP3). All platelet functional responses are governed by one or both of these signals. Some known calcium-sensitive proteins are indicated with red dots. Direct activation is shown by solid green arrows, direct inhibition by solid red arrows. Indirect interactions are shown by dashed lines. Abbreviations. AC adenylate cyclase, AR - $\alpha 2 A$-adrenergic receptor, CDGEF - CalDAGGEFI, COX - cyclooxygenase, DAG - diacylglycerol, DTS - dense tubular system, IP3R - receptor for inositol-1,4,5-trisphosphate (IP3), Mit - a mitochondrion, mPTP mitochondrial permeability transition pore, NCLX - mitochondrial sodium/calcium exchanger, OCS - open canalicular system, P2Y - purinergic receptor, PAR - protease-activated receptor, PIP2 - phosphoinositol-4,5-bisphosphate, PIP3 - phosphoinositol-3,4,5-trisphosphate, PKA - protein kinase A, PKC - protein kinase C, PL - phospholipid, PLA2 phospholipase A2, PMCA - plasma membrane calcium ATPase, PR - PGI2 receptor, SERCA - sarcoplasmic/endoplasmic reticulum calcium ATPase, TR - thromboxane A2 (TXA2) receptor, TRPC - transient receptor potential channel, UNI mitochondrial uniporter, $\mathrm{Va}$ - factor Va, vWF - von Willebrand Factor.

signalling pathway, different dose-dependence for different responses to the same agonist caused by it, principles of signal encoding and de-coding are rarely discussed even beyond the platelet field [19], and almost never for platelets.

Another not usually discussed point in platelet receptor-response relationship is the mechanosensitivity of these cells, whose whole life is spent in fast streams of blood. There is enough evidence that platelets can "sense" the shear rate of the blood stream and even turbulence of the flow [20-23]. However, this question will be discussed in the next part of this review, as here our goal is to address issues of responses rather than receptors. We shall highlight the main principles of platelet signal processing and decision-making, with the focus not on the description of signalling pathways but rather on the attempt to characterize how they work together to achieve different sets of physiologically relevant responses depending on the situation.

\section{Functional Responses and Their Immediate Causes}

Here we shall mostly focus on the platelet responses relevant to hemostasis, because they are believed to be more comprehensively studied. The minimal set of main platelet functions implemented in response to injury usually includes integrin allb $\beta 3$ activation [24], dense granule release [25], alphagranule release [26], thromboxane A2 synthesis, shape change, procoagulant activity [27], and contraction [28] (Fig. 1). The initial adhesion to von Willebrand factor mediated by glycoprotein $\mathrm{lb}$ is not included among them because it does not require platelet activation [29]. It should be noted that these functions are probably not equally important, or rather not all of them were reliably shown to contribute to hemostatis.

\section{Integrin activation}

Integrin activation is probably the one response 


\section{SBP I' Reports}

believed to be the most vitally important as demonstrated by severe bleeding in their deficiency, Glanzmann's thrombasthenia [30]. Platelets have about 100000 integrin allb $\beta 3$ molecules per cell that are capable to radically increase their affinity to von Willebrand factor and fibrinogen thus directly mediating aggregate formation [24]. All platelet agonists, including biomechanical platelet activation via the vWf-glycoprotein Ib axis, are believed to cause integrin activation to some degree [31]. This response is gradual, probably with the intermediate activation states [21]. The immediate cause of the integrin transition between the states is formation of a large cytoskeleton-associated complex of proteins at the cytosolic side of the plasmatic membrane. The critical structural role in this complex is played by proteins talin-1 [32] and kindlin-3 [33], while the signal transduction switch triggering its formation is believed to be small soluble cytosolic GTPase, Rap1-GTP [31,32,34]. In addition to allbß3, platelets have a number of other integrins specific to collagen, fibronectin, laminin and other molecules; their significance is less certain, while the activation mechanisms appear to be similar $[31,35,36]$.

\section{Dense granule release}

Dense (or delta-, $\delta$-) granules are platelet-specific organelles released upon stimulation $[25,37,38]$. They contain mostly low-molecular-weight compounds, the major of them being ADP able to activate other platelets [39]. Another component that has been recently attracting a lot of attention is polyphosphate reported to have a number of potential roles in the coagulation cascade $[40,41]$. The functional role of other dense granule components such is ATP, serotonin, calcium is much less clear $[41,42]$. In contrast to integrin activation, dense granule release is not easily mediated by all activators; for example, ADP itself causes it only to a very minor degree [43]. The intracellular mechanism of differential dense granule release is still controversial $[37,38]$ and will be discussed in the next part of this Review. The essential signal transduction switch mediating these processes is believed to be various isoforms of protein kinase $C[44,45]$ and phosphatidylinositol content of their membranes $[46,47]$.

\section{Alpha granule release}

Alpha ( $\alpha-)$ granules are another type of platelet not necessarily spherical [48] intracellular vesicles released upon activation, which have specific cargo composed mostly of proteins including fibrinogen, von Willebrand factor, factor V, C1 inhibitor, growth factors, and other molecules [26,49]. Membranes of alpha-granules have additional integrins and P-selectin. Some of the studies suggest that contactpathway-activating components of platelets are associated with alpha granules, and not dense granules [50]. There is evidence that there are subtypes of alpha-granules with different content released upon different stimulation [51]. The proteins in alpha-granules are involved in platelet aggregation, coagulation, angiogenesis, immunity, inflammation, vessel wall integrity maintenance/repair and other vital processes $[5,52,53]$. However, the only component of alpha granules whose hemostatic function is well established is factor $V$, which is present there in significant quantities and in partially activated form, and whose importance is confirmed by patient and animal studies [54,55]. Alpha-granule proteins remain associated with procoagulant platelets [56] by forming a fibrin polymerizationdependent and transglutaminase- dependent "cap" [57]. Its function is not completely clear, although they were shown to mediate procoagulant platelet attachment to aggregates [58]. The release of alpha granules is believed to be produced by almost all platelet activators [59-61].

\section{Procoagulant activity.}

Acceleration of the membrane-dependent reactions of blood coagulation occurs on the surface of the specific platelet subpopulation, called procoagulant platelets; recent data suggest that there is even a special dedicated cell structure for this [62]. Therefore, this response is a bit different from other responses, which are more uniformly distributed among platelet. Interestingly, integrins are inactivated in this subpopulation at some timepoint of procoagulant platelet formation [63]. The procoagulant platelets are formed upon strong stimulation with thrombin or glycoprotein VI agonists as a result of necrosis process [64], caused by accumulation of calcium by the mitochondria $[65,66]$. However, other activators such as ADP are capable of fine-tuning procoagulant platelet formation [67].

\section{Other responses.}

The earliest platelet response to any activation, even very slight one, is shape change from an ellipsoid to a sphere associated with reorganization of peripheral microtubule ring $[68,69]$. However, functional importance of this transition is not clear. The next level of shape change is formation of lamellipodia and filopodia leading to increased surface of contact with other platelets and vascular wall [70]. These stages are caused by actin cytoskeleton rearrangements $[70,71]$, potently induced by thrombin, followed by ADP, but less by collagen [71]. Platelets ability to change their shape significantly affects packing of platelets within thrombus, and results in increased platelet density and decreased porosity [72]. However, the necessity of this response is unclear, as the disregulated actin polymerization in patients with Wiscott-Aldrich syndrome cause smaller platelet formation rather than platelet disfunction 


\section{SBP I Reports}

\section{alpha granules dense granules integrins}

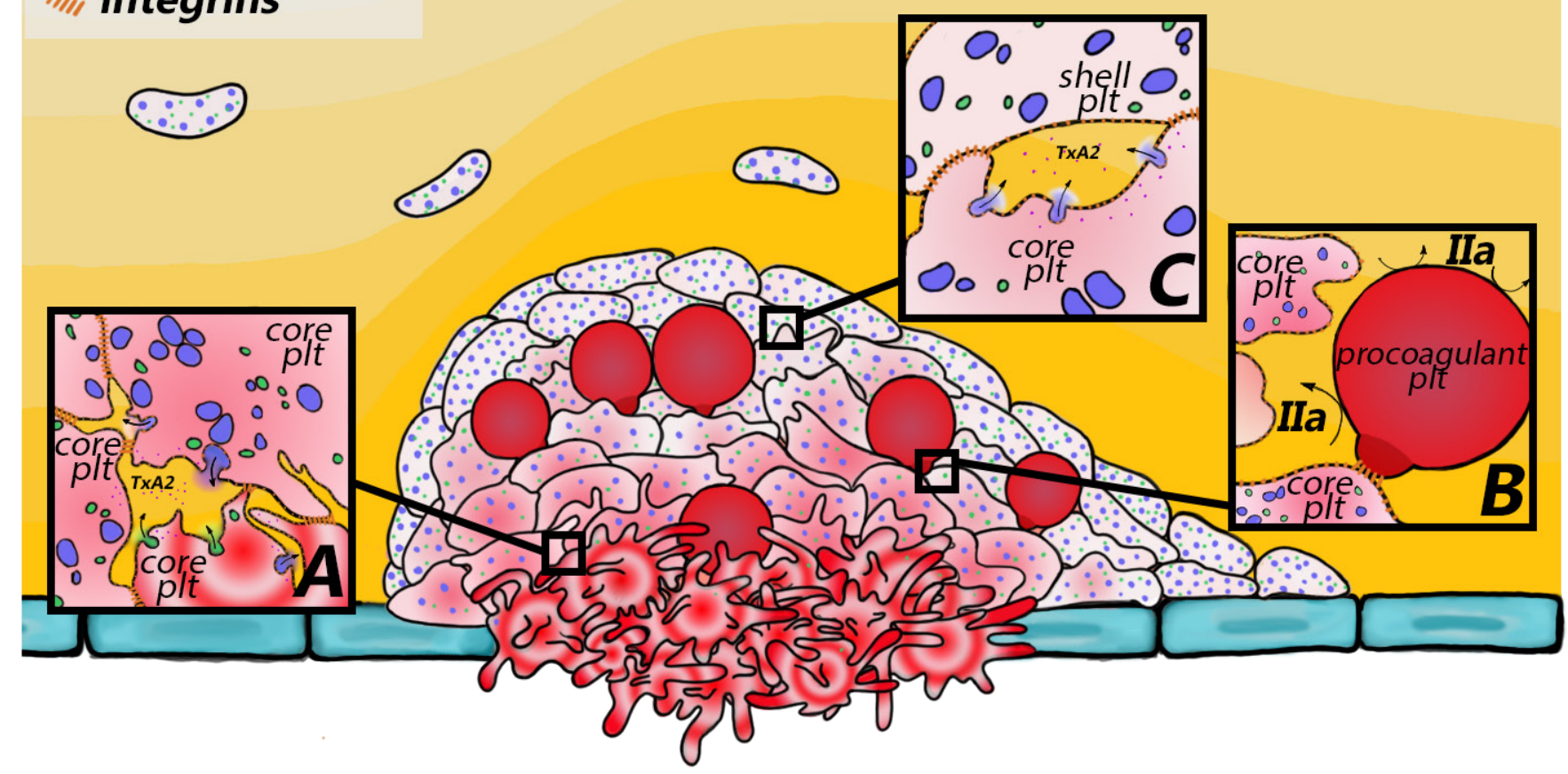

Figure 3. Platelet functional responses within arterial thrombus. The thrombus is conditionally divided into two regions, the "core" and the "shell" [86]. Platelet cytosolic calcium concentration is shown by shades of red, circles indicate oscillations. The intensity of calcium signaling is supposed to reflect the level of platelet activation. Cell trajectories in the bloodstream are demonstrated by means of gradient yellow. (A) Thrombus "core" is composed of degranulated platelets that have formed filopodia and lamellipodia and slightly less activated platelets closely adjacent to them. These activated platelets release the contents of dense and alpha granules (shown by arrows) and thromboxane (shown in purple dots) in the lumen between the cells. Integrins bind fibrinogen, thus forming "bridges" between neighboring platelets (orange lines). (B) Procoagulant platelets provide their surface for membrane-dependent reactions of plasma coagulation ultimately catalyzing thrombin (Ila) formation. Over time, they're pushed up to the "shell" by the "core" platelets. (C) "Shell" platelets are disc-shaped and contain a large number of granules of both types. They're the last ones that have settled on the thrombus and are connected to it by integrin-fibrinogen-integrinbridges. Abbreviations: plt - platelet, TxA2 - thromboxane A2, Ila - blood coagulation factor Ila.

\section{$[66,73]$.}

Another early and easily induced response is thromboxane A2 synthesis mediated by phospholipase A2, cyclooxygenase (mostly, COX-1) and thromboxane synthase [74]. Thromboxane $A 2$ is a lipid eicosanoid acting upon platelets (like ADP) [75]. It is still not clear whether thromboxane is important for the same platelet that has released it. At the first step, arachidonic acid is produced from different membrane phospholipids, and the second step is that of thromboxane A2 formation. Interestingly, the regulated step is the first one, that of phospholipase A2. That is why resting platelets may produce thromboxane A2 upon addition of just arachidonic acid [76]. Platelets have two phospholipases A2, $\mathrm{C}$ - and I- isoforms. The former is activated by slight increase of cytosolic calcium concentration, and that is probably why all classic platelet activators cause thromboxane synthesis, while the latter is activated independent of calcium and its role in platelets is not yet established [77]. COX-1 is inactivated by aspirin and is one of the main targets for anti-aggregation therapy, suggesting importance of thromboxane A2 in arterial thrombus formation [78].

Platelet contraction, sometimes called "retraction", occurs at a later stage of plug/thrombus formation, and is mediated by classic actin/myosin mechanisms [79]. Contraction is observed in platelets activated by a variety of agonists. The studies of signal transduction pathways leading to clot contraction are lacking, although integrin "outside-in" signalling is known to be crucial for this process [80]. Also, a calcium-dependent enzyme, myosin II light chain kinase (MLCK) is involved during clot retraction [81]. Recent studies suggested that contraction may play a role in re-arranging thrombus architecture, e.g. expelling procoagulant platelets to the platelet thrombus periphery to form fibrin there [27], organizing ischemic thrombi [82], or increasing platelet concentration at the fibrin clot periphery, also mechanically increasing local fibrin density [83].

\section{Conclusions}

Some of the platelet responses are critical for 
platelet plug formation (integrins, dense granules, thromboxane A2), while others are involved in blood coagulation (procoagulant activity, alpha-granules); yet other responses while being important have less clearly defined area of applicability, such as contraction and shape change.

These responses are spatiotemporally organized: they occur at different stages in different parts of the thrombi (Fig. 3). Integrin activation of different degree is responsible for forming the whole body of the thrombus, both the dense parts of highly activated platelets and loosely activated external regions; dense granule release is vital for the activation of platelets distal from the damaged region; alphagranules and procoagulant surfaces are vital for fibrin formation and thrombus solidification.

In order to achieve this, platelet activation responses form a hierarchy of strength: some of them are induced by all or most agonists (alpha granule release, weak integrin activation), while others require potent stimulation (procoagulant activity), with all shades of gray in-between. Some of the responses are gradual meaning that the response is gradually increased within a wide range of activation conditions (dense granules), while others are triggerlike meaning that they either completely implemented or not at all (alpha granules).

The in-depth analysis of the signalling pathways interaction, encoding and decoding of information, which give rise to these properties, are considered in the next part of this review. As a post-note it is worth mentioning that the computational biology approach $[14,84,85]$ greatly facilitates our understanding of the platelet receptor-function relationship.

\section{Author Contributions}

A.N.S. drew the figures, wrote the text and edited the paper; M.G.S. drew the figures; M.A.P. supervised the project, wrote the text and edited the paper. All authors have read and agreed to the published version of the manuscript.

\section{Conflicts of Interest}

The authors declare no conflict of interest

\section{Funding}

The study was supported by Russian Science Foundation (Grant 21-74-20087).

\section{References}

1. Panteleev MA, Dashkevich NM, Ataullakhanov FI. Hemostasis and thrombosis beyond biochemistry: roles of geometry, flow and diffusion. Thromb Res 2015;136:699-711. https://doi.org/10.1016/j. thromres.2015.07.025.

2. Getz TM, Piatt R, Petrich BG, Monroe D, Mackman $\mathrm{N}$, Bergmeier $\mathrm{W}$. Novel mouse hemostasis model for real-time determination of bleeding time and hemostatic plug composition. Journal of Thrombosis and Haemostasis 2015;13:417-25. https://doi.org/10.1111/jth.12802.

3. Panteleev MA, Saenko EL, Ananyeva NM, Ataullakhanov FI. Kinetics of Factor $X$ activation by the membrane-bound complex of Factor IXa and Factor VIIla. Biochem J 2004;381:779-94. https://doi.org/10.1042/BJ20031748.

4. Podoplelova NA, Sveshnikova AN, Kurasawa $\mathrm{JH}$, Sarafanov AG, Chambost H, Vasil'Ev SA, et al. Hysteresis-like binding of coagulation factors $\mathrm{X} / \mathrm{Xa}$ to procoagulant activated platelets and phospholipids results from multistep association and membrane-dependent multimerization. Biochimica et Biophysica Acta (BBA)Biomembranes 2016;1858:1216-27.

5. Deppermann C. Platelets and vascular integrity. Platelets 2018;29:549-55. https://doi.org/10.1080 /09537104.2018.1428739.

6. Martyanov AA, Kaneva VN, Panteleev MA, Sveshnikova AN. Physiological and pathophysiological aspects of blood platelet activation through CLEC-2 receptor. Oncohematology 2018;13:83-90.

7. Ho-Tin-Noé B, Demers M, Wagner DD. How platelets safeguard vascular integrity: Platelets and vascular integrity. Journal of Thrombosis and Haemostasis 2011;9:56-65. https://doi. org/10.1111/j.1538-7836.2011.04317.x.

8. Boulaftali Y, Hess PR, Getz TM, Cholka A, Stolla $\mathrm{M}$, Mackman N, et al. Platelet ITAM signaling is critical for vascular integrity in inflammation. $\mathrm{J}$ Clin Invest 2013:JCl65154. https://doi.org/10.1172/ JCl65154.

9. Schattner $M$, Jenne $C N$, Negrotto $S$, HoTin-Noe B. Editorial: Platelets and Immune Responses During Thromboinflammation. Front Immunol 2020;11:1079. https://doi.org/10.3389/ fimmu.2020.01079.

10. Rayes J, Bourne JH, Brill A, Watson SP. The dual role of platelet-innate immune cell interactions in thrombo-inflammation. Research and Practice in Thrombosis and Haemostasis 2020;4:23-35. https://doi.org/10.1002/rth2.12266.

11. Nebie O, Barro L, Wu Y-W, Knutson F, Buée L, Devos D, et al. Heat-treated human platelet pellet lysate modulates microglia activation, favors wound healing and promotes neuronal differentiation in vitro. Platelets 2020;0:1-12. https://doi.org/10.1080/09537104.2020.1732324.

12. Wojtukiewicz MZ, Sierko E, Hempel D, Tucker SC, Honn KV. Platelets and cancer angiogenesis nexus. Cancer Metastasis Rev 2017;36:249-62. https://doi.org/10.1007/s10555-017-9673-1.

13. Panteleev MA, Sveshnikova AN. Platelets and hemostasis. Oncohematology 2014;9:65-73.

14. Dunster JL, Panteleev MA, Gibbins JM, Sveshnikova AN. Mathematical Techniques for Understanding Platelet Regulation and the Development of New Pharmacological Approaches. In: Gibbins JM, Mahaut-Smith M, editors. Platelets and Megakaryocytes: Volume 
4, Advanced Protocols and Perspectives, New York, NY: Springer; 2018, p. 255-79. https://doi. org/10.1007/978-1-4939-8585-2_15.

15. Coxon $\mathrm{CH}$, Geer MJ, Senis YA. ITIM receptors: more than just inhibitors of platelet activation. Blood 2017;129:3407-18. https://doi.org/10.1182/ blood-2016-12-720185.

16. Geer MJ, van Geffen JP, Gopalasingam P, Vögtle T, Smith CW, Heising S, et al. Uncoupling ITIM receptor G6b-B from tyrosine phosphatases Shp1 and Shp2 disrupts murine platelet homeostasis. Blood 2018;132:1413-25. https://doi.org/10.1182/ blood-2017-10-802975.

17. Scheibel M, Klein B, Merkle H, Schulz M, Fritsch R, Greten $\mathrm{FR}$, et al. IKB $\beta$ is an essential co-activator for LPS-induced IL-1 $\beta$ transcription in vivo. Journal of Experimental Medicine 2010;207:2621-30. https://doi.org/10.1084/jem.20100864.

18. Inman BA, Frigola $\mathrm{X}$, Dong $\mathrm{H}$, Kwon ED. Costimulation, Coinhibition and Cancer. Current Cancer Drug Targets 2007;7:15-30. https://doi. org/10.2174/156800907780006878.

19. Vinayagam A, Stelzl U, Foulle R, Plassmann $\mathrm{S}$, Zenkner $\mathrm{M}$, Timm J, et al. A Directed Protein Interaction Network for Investigating Intracellular Signal Transduction. Science Signaling 2011;4:rs8-rs8. https://doi.org/10.1126/ scisignal.2001699.

20. Hansen CE, Qiu Y, McCarty OJT, Lam WA. Platelet Mechanotransduction. Annual Review of Biomedical Engineering 2018;20:253-75. https:// doi.org/10.1146/annurev-bioeng-062117-121215.

21. Chen Y, Ju LA, Zhou F, Liao J, Xue L, Su QP, et al. An integrin allb $\beta 3$ intermediate affinity state mediates biomechanical platelet aggregation. Nat Mater 2019;18:760-9. https://doi.org/10.1038/ s41563-019-0323-6.

22. Ilkan Z, Wright JR, Goodall AH, Gibbins JM, Jones $\mathrm{Cl}$, Mahaut-Smith MP. Evidence for shearmediated $\mathrm{Ca} 2+$ entry through mechanosensitive cation channels in human platelets and a megakaryocytic cell line. Journal of Biological Chemistry 2017;292:9204-17. https://doi. org/10.1074/jbc.M116.766196.

23. Ito $\mathrm{Y}$, Nakamura $\mathrm{S}$, Sugimoto $\mathrm{N}$, Shigemori T, Kato $\mathrm{Y}$, Ohno $\mathrm{M}$, et al. Turbulence Activates Platelet Biogenesis to Enable Clinical Scale Ex Vivo Production. Cell 2018;174:636-648.e18. https:// doi.org/10.1016/j.cell.2018.06.011.

24. Kaneva VN, Martyanov AA, Morozova DS, Panteleev MA, Sveshnikova AN. Platelet Integrin allbß3: Mechanisms of Activation and Clustering; Involvement into the Formation of the Thrombus Heterogeneous Structure. Biochem Moscow Suppl Ser A 2019;13:97-110. https://doi.org/10.1134/ S1990747819010033.

25. King SM, McNamee RA, Houng AK, Patel R, Brands $M$, Reed GL. Platelet dense granule secretion plays a critical role in thrombosis and subsequentvascular remodeling in atherosclerotic mice. Circulation 2009;120:785-91. https://doi. org/10.1161/CIRCULATIONAHA.108.845461.

26. Jr JEI, Battinelli EM. Selective sorting of alpha-granule proteins. Journal of Thrombosis and Haemostasis 2009;7:173-6. https://doi. org/10.1111/j.1538-7836.2009.03387.x.

27. Nechipurenko DY, Receveur N, Yakimenko AO, Shepelyuk TO, Yakusheva AA, Kerimov RR, et al. Clot contraction drives the translocation of procoagulant platelets to thrombus surface. Arteriosclerosis, Thrombosis, and Vascular Biology 2019;39:37-47.

28. Tutwiler V, Litvinov RI, Lozhkin AP, Peshkova AD, Lebedeva T, Ataullakhanov FI, et al. Kinetics and mechanics of clot contraction are governed by the molecular and cellular composition of the blood. Blood 2016;127:149-59. https://doi.org/10.1182/ blood-2015-05-647560.

29. Dong JF, Berndt MC, Schade A, McIntire LV, Andrews RK, López JA. Ristocetin-dependent, but not botrocetin-dependent, binding of von Willebrand factor to the platelet glycoprotein IbIX-V complex correlates with shear-dependent interactions. Blood 2001;97:162-8. https://doi. org/10.1182/blood.v97.1.162.

30. Nurden P, Stritt S, Favier R, Nurden AT. Inherited platelet diseases with normal platelet count: phenotypes, genotypes and diagnostic strategy. Haematologica 2021;106:337-50. https://doi. org/10.3324/haematol.2020.248153.

31. Stefanini L, Bergmeier W. RAP GTPases and platelet integrin signaling. Platelets 2019;30:41-7. https://doi.org/10.1080/09537104.2018.1476681.

32. Lagarrigue F, Paul DS, Gingras AR, Valadez AJ, Sun $H$, Lin J, et al. Talin-1 is the principal platelet Rap1 effector of integrin activation. Blood 2020;136:1180-90. https://doi.org/10.1182/ blood.2020005348.

33. Gao J, Huang M, Lai J, Mao K, Sun P, Cao Z, et al. Kindlin supports platelet integrin allb $\beta 3$ activation by interacting with paxillin. J Cell Sci 2017;130:3764-75. https://doi.org/10.1242/ jcs.205641.

34. Stefanini L, Boulaftali $Y$, Ouellette TD, Holinstat $M$, Désiré $L$, Leblond $B$, et al. Rap1-Rac1 circuits potentiate platelet activation. Arterioscler Thromb Vasc Biol 2012;32:434-41. https://doi.org/10.1161/ ATVBAHA.111.239194.

35. Mammadova-Bach E, Zigrino $P$, Brucker C, Bourdon $C$, Freund $M$, De Arcangelis $A$, et al. Platelet integrin $\alpha 6 \beta 1$ controls lung metastasis through direct binding to cancer cell-derived ADAM9. JCI Insight 2016;1:e88245. https://doi. org/10.1172/jci.insight.88245.

36. Lakshmanan HHS, Melrose AR, Sepp A-LI, Mitrugno A, Ngo ATP, Khader A, et al. The basement membrane protein nidogen-1 supports platelet adhesion and activation. Platelets 2020:15. https://doi.org/10.1080/09537104.2020.174517 0.

37. Cardenas El, Breaux K, Da Q, Flores JR, Ramos MA, Tuvim MJ, et al. Platelet Munc13-4 regulates hemostasis, thrombosis and airway inflammation. Haematologica 2018;103:1235-44. https://doi. org/10.3324/haematol.2017.185637.

38. Williams CM, Li Y, Brown E, Poole AW. Platelet- 
specific deletion of SNAP23 ablates granule secretion, substantially inhibiting arterial and venous thrombosis in mice. Blood Adv 2018;2:3627-36. https://doi.org/10.1182/ bloodadvances.2018023291.

39. Zheng TJ, Lofurno ER, Melrose AR, Lakshmanan HHS, Pang J, Phillips KG, et al. Assessment of the effects of Syk and BTK inhibitors on GPVImediated platelet signaling and function. Am J Physiol Cell Physiol 2021. https://doi.org/10.1152/ ajpcell.00296.2020.

40. Labberton L, Long AT, Gendler SJ, Snozek CL, Stavrou EX, Nickel KF, et al. A Flow Cytometry-Based Assay for Procoagulant Platelet Polyphosphate. Cytometry B Clin Cytom 2018;94:369-73. https://doi.org/10.1002/ cyto.b.21492.

41. Suess PM, Smith SA, Morrissey JH. Platelet polyphosphate induces fibroblast chemotaxis and myofibroblast differentiation. J Thromb Haemost 2020;18:3043-52. https://doi.org/10.1111/ jth.15066.

42. Chen Y, Yuan Y, Li W. Sorting machineries: how platelet-dense granules differ from a-granules. Biosci Rep 2018;38. https://doi.org/10.1042/ BSR20180458.

43. Leunissen TC, Wisman PP, van Holten TC, de Groot PG, Korporaal SJ, Koekman AC, et al. The effect of P2Y12 inhibition on platelet activation assessed with aggregation- and flow cytometrybased assays. Platelets 2017;28:567-75. https:// doi.org/10.1080/09537104.2016.1246713.

44. Harper MT, Poole AW. Diverse functions of protein kinase $\mathrm{C}$ isoforms in platelet activation and thrombus formation. J Thromb Haemost 2010;8:454-62. https://doi.org/10.1111/j.15387836.2009.03722.x.

45. Murugappan S, Tuluc F, Dorsam RT, Shankar H, Kunapuli SP. Differential role of protein kinase C delta isoform in agonist-induced dense granule secretion in human platelets. J Biol Chem 2004;279:2360-7. https://doi.org/10.1074/jbc. M306960200.

46. Li X, Garrity AG, Xu H. Regulation of membrane trafficking by signalling on endosomal and lysosomal membranes. J Physiol 2013;591:4389_ 401. https://doi.org/10.1113/jphysiol.2013.258301.

47. Ma C-IJ, Yang Y, Kim T, Chen CH, Polevoy G, Vissa $M$, et al. An early endosome-derived retrograde trafficking pathway promotes secretory granule maturation. J Cell Biol 2020;219. https:// doi.org/10.1083/jcb.201808017.

48. Pokrovskaya I, Tobin M, Desai R, Aronova MA, Kamykowski JA, Zhang G, et al. Structural analysis of resting mouse platelets by 3D-EM Reveals an unexpected variation in $\alpha$-granule shape. Platelets 2020:1-10. https://doi.org/10.1080/09537104.202 0.1799970.

49. Parsons MEM, Szklanna PB, Guerrero JA, Wynne K, Dervin F, O'Connell K, et al. Platelet Releasate Proteome Profiling Reveals a Core Set of Proteins with Low Variance between Healthy Adults. Proteomics 2018;18:e1800219. https://doi. org/10.1002/pmic.201800219.

50. Zakharova NV, Artemenko EO, Podoplelova NA, Sveshnikova AN, Demina IA, Ataullakhanov FI, et al. Platelet surface-associated activation and secretion-mediated inhibition of coagulation factor XII. PloS One 2015;10:e0116665.

51. Chatterjee M, Huang Z, Zhang W, Jiang L, Hultenby $\mathrm{K}$, Zhu L, et al. Distinct platelet packaging, release, and surface expression of proangiogenic and antiangiogenic factors on different platelet stimuli. Blood 2011;117:3907-11. https://doi.org/10.1182/ blood-2010-12-327007.

52. Rendu F, Brohard-Bohn B. The platelet release reaction: granules' constituents, secretion and functions. Platelets 2001;12:261-73. https://doi. org/10.1080/09537100120068170.

53. Sharda A, Flaumenhaft R. The life cycle of platelet granules. F1000Res 2018;7:236. https://doi. org/10.12688/f1000research.13283.1.

54. Golebiewska EM, Poole AW. Platelet secretion: From haemostasis to wound healing and beyond. Blood Reviews 2015;29:153-62. https://doi. org/10.1016/j.blre.2014.10.003.

55. Bouchard BA, Chapin J, Brummel-Ziedins KE, Durda P, Key NS, Tracy PB. Platelets and platelet-derived factor $\mathrm{Va}$ confer hemostatic competence in complete factor $\mathrm{V}$ deficiency. Blood 2015;125:3647-50. https://doi.org/10.1182/ blood-2014-07-589580.

56. Dale GL. Coated-platelets: an emerging component of the procoagulant response. J Thromb Haemost 2005;3:2185-92. https://doi. org/10.1111/j.1538-7836.2005.01274.x.

57. Abaeva AA, Canault M, Kotova YN, Obydennyy SI, Yakimenko AO, Podoplelova NA, et al. Procoagulant platelets form an a-granule proteincovered "cap" on their surface that promotes their attachment to aggregates. J Biol Chem 2013;288:29621-32. https://doi.org/10.1074/jbc. M113.474163.

58. Yakimenko AO, Verholomova FY, Kotova YN, Ataullakhanov $\mathrm{FI}$, Panteleev MA. Identification of different proaggregatory abilities of activated platelet subpopulations. Biophys J2012;102:22619. https://doi.org/10.1016/j.bpj.2012.04.004.

59. Allman-Farinelli MA, Bendall L, Troy J, Versluis C, Hall D, Favaloro EJ, et al. A simple, whole blood method for assessment of platelet function: application to dietary intervention. Thromb Res 1998;90:163-9. https://doi.org/10.1016/s00493848(98)00030-9.

60. Graff J, Klinkhardt U, Schini-Kerth VB, Harder $\mathrm{S}$, Franz N, Bassus $\mathrm{S}$, et al. Close relationship between the platelet activation marker CD62 and the granular release of platelet-derived growth factor. J Pharmacol Exp Ther 2002;300:952-7. https://doi.org/10.1124/jpet.300.3.952.

61. Quinton TM, Murugappan S, Kim S, Jin J, Kunapuli SP. Different $G$ protein-coupled signaling pathways are involved in alpha granule release from human platelets. J Thromb Haemost 2004;2:978-84. https://doi.org/10.1111/j.1538-7836.2004.00741.x.

62. Podoplelova NA, Sveshnikova AN, Kotova YN, 
Eckly A, Receveur N, Nechipurenko DYu, et al. Coagulation factors bound to procoagulant platelets concentrate in cap structures to promote clotting. Blood 2016;128:1745-55. https://doi. org/10.1182/blood-2016-02-696898.

63. Mattheij NJA, Gilio K, van Kruchten R, Jobe SM, Wieschhaus AJ, Chishti AH, et al. Dual Mechanism of Integrin allbß3 Closure in Procoagulant Platelets*. Journal of Biological Chemistry 2013;288:13325-36. https://doi.org/10.1074/jbc. M112.428359.

64. Jackson SP, Schoenwaelder SM. Procoagulant platelets: are they necrotic? Blood 2010;116:20118. https://doi.org/10.1182/blood-2010-01-261669.

65. Sveshnikova AN, Ataullakhanov FI, Panteleev MA. Compartmentalized calcium signaling triggers subpopulation formation upon platelet activation through PAR1. Mol BioSyst 2015;11:1052-60. https://doi.org/10.1039/C4MB00667D.

66. Obydennyi SI, Artemenko EO, Sveshnikova AN, Ignatova AA, Varlamova TV, Gambaryan S, et al. Mechanisms of increased mitochondriadependent necrosis in Wiskott-Aldrich syndrome platelets. Haematologica 2020;105:1095-106.

67. Shakhidzhanov SS, Shaturny VI, Panteleev MA, Sveshnikova AN. Modulation and pre-amplification of PAR1 signaling by ADP acting via the P2Y12 receptor during platelet subpopulation formation. Biochimica et Biophysica Acta (BBA)-General Subjects 2015;1850:2518-29.

68. Diagouraga B, Grichine A, Fertin A, Wang J, Khochbin S, Sadoul K. Motor-driven marginal band coiling promotes cell shape change during platelet activation. J Cell Biol 2014;204:177-85. https://doi.org/10.1083/jcb.201306085.

69. Cuenca-Zamora EJ, Ferrer-Marín F, Rivera J, Teruel-Montoya R. Tubulin in Platelets: When the Shape Matters. Int J Mol Sci 2019;20. https://doi. org/10.3390/ijms20143484.

70. Poulter NS, Pollitt AY, Davies A, Malinova D, Nash $\mathrm{GB}$, Hannon MJ, et al. Platelet actin nodules are podosome-like structures dependent on Wiskott-Aldrich syndrome protein and ARP2/3 complex. Nat Commun 2015;6:7254. https://doi. org/10.1038/ncomms8254.

71. Bender M, Palankar R. Platelet Shape Changes during Thrombus Formation: Role of Actin-Based Protrusions. Hamostaseologie 2021;41:14-21. https://doi.org/10.1055/a-1325-0993.

72. Mirramezani M, Herbig BA, Stalker TJ, Nettey L, Cooper M, Weisel JW, et al. Platelet packing density is an independent regulator of the hemostatic response to injury. J Thromb Haemost 2018;16:973-83. https://doi.org/10.1111/ jth.13986.

73. Shcherbina A, Cooley J, Lutskiy MI, Benarafa C, Gilbert GE, Remold-O'Donnell E. WASP plays a novel role in regulating platelet responses dependent on allb $\beta 3$ integrin outside-in signalling. British Journal of Haematology 2010;148:416-27. https://doi.org/10.1111/j.1365-2141.2009.07959.x.

74. Russo I, Penna C, Musso T, Popara J, Alloatti G, Cavalot $F$, et al. Platelets, diabetes and myocardial ischemia/reperfusion injury. Cardiovasc Diabetol 2017;16. https://doi.org/10.1186/s12933-0170550-6.

75. Barinov EF. [Thromboxane A2: Mechanisms of Synthesis and Intracellular Signaling System of Realization]. Kardiologiia 2016;56:83-90. https:// doi.org/10.18565/cardio.2016.4.83-90.

76. Olechowski B, Ashby A, Mariathas M, Khanna V, Mahmoudi M, Curzen N. Is arachidonic acid stimulation really a test for the response to aspirin? Time to think again? Expert Rev Cardiovasc Ther 2017;15:35-46. https://doi.org/10.1080/14779072 .2017 .1266255 .

77. Yoda E, Rai K, Ogawa M, Takakura Y, Kuwata H, Suzuki $\mathrm{H}$, et al. Group VIB calcium-independent phospholipase A2 (iPLA2 $\gamma$ ) regulates platelet activation, hemostasis and thrombosis in mice. PLoS One 2014;9:e109409. https://doi. org/10.1371/journal.pone.0109409.

78. Tomaiuolo M, Brass LF, Stalker TJ. Regulation of platelet activation and coagulation and its role in vascular injury and arterial thrombosis. Interv Cardiol Clin 2017;6:1-12. https://doi.org/10.1016/j. iccl.2016.08.001.

79. Johnson GJ, Leis LA, Krumwiede MD, White JG. The critical role of myosin IIA in platelet internal contraction. J Thromb Haemost 2007;5:1516-29. https://doi.org/10.1111/j.1538-7836.2007.02611.x.

80. Schoenwaelder SM, Yuan Y, Cooray P, Salem HH, Jackson SP. Calpain Cleavage of Focal Adhesion Proteins Regulates the Cytoskeletal Attachment of Integrin allbß3 (Platelet Glycoprotein IIb/llla) and the Cellular Retraction of Fibrin Clots *. Journal of Biological Chemistry 1997;272:1694-702. https:// doi.org/10.1074/jbc.272.3.1694.

81. Egot $M$, Kauskot A, Lasne $D$, Gaussem $P$, Bachelot-Loza C. Biphasic myosin II light chain activation during clot retraction. Thromb Haemost 2013;110:1215-22. https://doi.org/10.1160/TH1304-0335.

82. Khismatullin RR, Nagaswami C, Shakirova AZ, Vrtková A, Procházka V, Gumulec J, et al. Quantitative Morphology of Cerebral Thrombi Related to Intravital Contraction and Clinical Features of Ischemic Stroke. Stroke 2020;51:3640-50. https://doi.org/10.1161/ STROKEAHA.120.031559.

83. Kovalenko TA, Giraud M-N, Eckly A, Ribba A-S, Proamer F, Fraboulet $S$, et al. Asymmetrical Forces Dictate the Distribution and Morphology of Platelets in Blood Clots. Cells 2021;10:584. https://doi.org/10.3390/cells10030584.

84. Dunster JL, Unsworth AJ, Bye AP, Haining EJ, Sowa MA, Di $Y$, et al. Interspecies differences in protein expression do not impact the spatiotemporal regulation of glycoprotein $\mathrm{VI}$ mediated activation. Journal of Thrombosis and Haemostasis 2020;18:485-96. https://doi. org/10.1111/jth.14673.

85. Martyanov AA, Balabin FA, Dunster JL, Panteleev MA, Gibbins JM, Sveshnikova AN. Control of Platelet CLEC-2-Mediated Activation by Receptor Clustering and Tyrosine Kinase Signaling. 
Biophysical Journal 2020;118:2641-55. https:// doi.org/10.1016/j.bpj.2020.04.023.

86. Stalker TJ, Traxler EA, Wu J, Wannemacher KM, Cermignano SL, Voronov R, et al. Hierarchical organization in the hemostatic response and its relationship to the platelet-signaling network. Blood 2013;121:1875-85. https://doi.org/10.1182/ blood-2012-09-457739. 